\title{
FORMATION AND INFILL OF RECENTLY DISCOVERED BURIED PLEISTOCENE TUNNEL VALLEYS IN THE NORTH SEA
}

T. Mörz (1), D. Hebbeln (1), H. Keil (2), D.A. Hepp (2), T. Schwenk (1), V. Spiess (1), J. Ehlers (3) (1): MARUM - Center for Marine Environmental Sciences, University of Bremen, P.O. Box 330440, 28334 Bremen, Germany

(2): Department of Geosciences, University of Bremen, P.O. Box 330440, 28334 Bremen, Germany (3): Geologisches Landesamt, Billstr. 84, 20539 Hamburg, Germany e-mail : tmoerz@uni-bremen.de

\section{Introduction}

The release of meltwater from the margins of the Late Quaternary Fennoscandian ice sheets resulted in complex networks of (now buried) Pleistocene tunnel-valleys that extend beneath large parts of the North Sea and the adjacent northern European lowlands. Deeply incised (100-500 m) into mostly Neogene sediment strata, they form a dominant architectural element of the North Sea sedimentary basin and are a primary cause of small scale lithological heterogeneities. Offshore mapping based on seismic surveys has provided evidence of multiple generations of buried valleys, inferred to record at least three successive cycles of continental glaciation and interglacial marine transgression. The largest known buried valleys lie in and adjacent to the southern North Sea and have been tentatively correlated to the mid-Pleistocene Elsterian glaciation based on marine muds of inferred Holsteinian interglacial age in the upper parts of their fill. However, absolute dating of all these systems is poor and there is a mismatch between wellsampled but poorly imaged onshore systems versus geophysically well-imaged but poorly sampled offshore systems. The recent discovery of a so far unknown major East-West trending buried valley system in the Southeast North Sea is more than $35 \mathrm{~km}$ long and apparently crosscuts older North-South trending valleys. The buried valley poses new multi-disciplinary questions with regard to the ages of cross-cutting features, their infill architecture and lithology, the orientations and dynamics of former ice margins, and the number and nature of interglacial marine transgressions. As tunnel-valleys are thought to form by melt water drainage beneath and perpendicular to ice sheet margins, an East-West trending postElsterian valley in the Southeast North Sea implies a North-South trending ice margin of Saalian (?) age, which previously has not been proposed for the German North Sea sector but would fit observations in the Dutch sector. Most of the buried valleys in the North Sea and the adjacent northern European lowlands are filled with a glaciofluvial backfill, deposited close to the retreating ice margin. Their upper parts often contain also younger well-layered muddy glacio-lacustrine and/or glaciomarine sediments deposited during subsequent interglacial transgressions (e.g., Holsteinian and Eemian) and glacial advances. First indications for earlier onsets of the Holsteinian and Eemian transgressions in the interglacial compared to the Holocene were deduced from terrestrial palynological investigations. Remnants of these older transgressive sequences are commonly eroded by glacial advances during the following Saalian and Weichselian glaciations, but are partly preserved in the Pleistocene buried valleys. In a proposed research project starting in July; seismic mapping and absolute dating of transgressive sequences from different depth horizons picked from drill cores will provide information on the development of the individual postglacial transgressions in the North Sea and relative timing of valley formation and infill events. Further interest - and the chance to collect samples - is stimulated by the fact that such valleys form lithological heterogeneities with abrupt changes in facies posing potential geotechnical risks in offshore wind farm planning and construction. 